takes up a considerable fraction of the book, and there is finally a section labelled plastics engineering, an omnibus title that includes such diverse topics as plasticizers, laminates and radio-frequency heating. Author and subject indexes conclude the volume.

In view of the origin of the book, it will be seen that this volume is one for the active worker in the subject. The abstracts are concentrated digests of papers with a sufficiency of detail to make it unnecessary in many cases to look up the original literature if only the numerical results are required. The reader has naturally to use his own critical judgment of the value of the work.

The letterpress of the volume has presumably been reproduced photographically from the loose-leaf abstracts; but the reproduction is of a high standard. As the publishers rightly remark, if the abstracts had been reset in type, the price of the book would have been much higher. Such a resetting is not really necessary in a book of this kind. A further volume is promised soon, dealing with specific types of high polymers. These volumes then can take their place with the abstract service of Rubbers, Resins and Plastics, starting in 1947.

H. W. Melville

\section{BIRDS OF NANTUCKET}

\section{The Birds of Nantucket}

By Ludlow Griscom and Edith V. Folger. England Bird Studies, 1.) Pp xi+156+16 p (Cambridge, Mass. : Harvard University Press ; London : Oxford Univerg ny Press, 1948.) 18s. net. 7 HE island of Nartucket is some thirty miles off the south r ficast of the State of Massachusetts, and has an trea of about forty-five square miles. Various Psmall islands, such as Tuckernuck and Muskege?, to the north-west are included in the area. Th ndigenous fauna consists of a few small mammals and some eight birds, so far as can be estimated from old records. The flora is likewise limited, but Scotch firs have been planted and the heather brought with them has become established in places. In sheltered hollows and near the towns there are deciduous trees.

Formerly whaling and fishing vessels were based on the island. In the winter many of the fishermen shot wild fowl for the market, and from 1870 onward sportsmen came from the mainland to shoot. Before long, ducks and wading birds began to decrease seriously in numbers; but now there is little shootingfield-glasses are replacing guns. The island has to-day become a summer resort, and birds of all kinds are increasing in numbers again. In 1870 Brewster estimated that several thousands of common terms nested on the north coast of Nantucket; but four years later this colony was depleted. Plumage hunters are said to have killed 40,000 of these terns in one year. So much for human interference. But in 1890 Brewster computed that the common tern colony on Muskeget numbered 20,000 birds. A few years later these numbers had decreased, and gradually the laughing gulls breeding there increased, so that by 1936 there were 30,000 of them. Then herring gulls also commenced to breed in the same area and by 1946 numbered 2,500 , with a corresponding decrease in the laughing gulls and terns.

Owing to the exposed position of Nantucket the shoals and sandbanks around the island are continually shifting, and this seriously affects the feeding grounds of the diving ducks. Little spring migration is seen on the island, though in the autumn considerable numbers of birds pass through. The authors consider that there is a large mortality among passerine birds in the autumn migration. They have observed a warbler start off from the south low over the sea, only to be overwhelmed by a large wave. Others are regularly noted on steamers as far as fifty miles out, and apparently must suffer the same fate. In the systematic list the status of each species is given in a comparative manner, definite counts are recorded where possible, and a point is made of stating what is not known about certain species.

This interesting little work is illustrated with some beautiful photographs by Allan Cruickshank. N. B. KINNEAR

\section{FISHES AND FISHERIES OF THE GOLD COAST}

The Fishes and Fisheries of the Gold Coast

By F. R. Irvine; with Illustrations and an Account of the Fishing Industry/ A. P. Brown, and Class. ification and Keys for the Identification of the Fishes, by the late J. T Norman and by E. Trewavas. (Püb. lished on behalf of the Government of the Gold Coast.) Jp: xvi+352. (London: Crown Agents for the Coloni.s, 1947.) 6s. net.

Phoris. HIS valuable book is based on collections originally made by the author for teaching pur. poses at Achimota College, near Accra. But, as the collection grew, interest in it spread both within and without the Gold Coast, and a more ambitious collection of named duplicates was built up. Most of the identifications were made by the late Mr. J. R. Norman and Miss E. Trewavas, of the British Museum (Natural History), from specimens sent to them there. Dr. F. R. Irvine was fortunate in also enlisting the help of his colleague, Mr. A. P. Brown, art master at the College, whose excellent drawings are a valuable feature of the book. The arrangement is based on a systematic classification provided by Norman, who also prepared artificial keys to the families, genera and species. Both marine and freshwater fishes are included. The provision of vernacular names should prove of much value to future workers in the Gold Coast region.

An important section of the book is devoted to a study of the fishing industry of the Labadi district, near Accra, and this is written by Brown. It is a most valuable contribution and may well be taken as a pattern by anyone making a similar study of native fisheries elsewhere. Another small section of the book is devoted to some of the larger and more important Gold Coast crustacea, most of which are edible and therefore appear on the markets. The descriptions are accompanied by excellent drawings and should make a useful basis for further and more detailed study of these animals in that region. Brief reference is also made to cetaceans, turtles and the African manatee.

It seems a pity that the title, to most people, will not indicate the full scope of the book. Perhaps this can be corrected if another edition is called for-as it almost certainly will be when the West African Colonies become more fully opened up to commercial fishing and research, and more becomes known about the aquatic faunas of that great region. 